\title{
Erratum to: Response of Bacteria to Mechanical Stimuli
}

\author{
S. S. Evstigneeva ${ }^{a}$, E. M. Telesheva ${ }^{a}$, D. I. Mokeev ${ }^{a}$, I. V. Borisov ${ }^{a}$, \\ L. P. Petrova ${ }^{a, * *}$, and A. V. Shelud'ko ${ }^{a, *}$ \\ ${ }^{a}$ Institute of Biochemistry and Physiology of Plants and Microorganisms, Russian Academy of Sciences, Saratov, 410049 Russia \\ *e-mail:shel71@yandex.ru \\ **e-mail:petrova_lp@mail.ru \\ Received October 28, 2021; revised October 28, 2021; accepted October 28, 2021
}

DOI: $10.1134 / \mathrm{S} 0026261722120013$

The article "Response of Bacteria to Mechanical Stimuli", written by S. S. Evstigneeva, E. M. Telesheva, D. I. Mokeev, I. V. Borisov, L. P. Petrova, and A. V. Shelud'ko, was originally published electronically in Springer-Link on 4 October 2021 without Open Access. After publication in volume 90, issue 5, pages 558-568 the authors decided to make the article an Open Access publication. Therefore, the copyright of the article has been changed to (C) The Author(s) 2021 and the article is forthwith distributed under the terms of a
Creative Commons Attribution 4.0 International License (http://creativecommons.org/licenses/by/4.0/, CC BY), which permits use, duplication, adaptation, distribution and reproduction of a work in any medium or format, as long as you cite the original author(s) and publication source, provide a link to the Creative Commons license, and indicate if changes were made.

The original article can be found online at https://doi.org/10.1134/S0026261721050052 